October - 2002

\title{
Global and Critical Visions of Distance Universities and Programs in Latin America
}

\author{
Miguel Casas Armengol \\ Universidad Nacional Abierta (UNA)
}

\begin{abstract}
The future of any region's higher education infrastructure cannot be a matter of guesswork; instead it must be built upon a solid foundation that is both rationally and soundly constructed. This postulate is especially important for regions such as Latin America experiencing problems associated with underdevelopment. Universities, particularly those specializing the area of science and technology, can and do play a constructive role in the advancement and improvement of modern society. However, the current Latin American educational context, which is less than optimal, can be compared with other similarly developing countries around the world, many of which have produced high quality university and scientific systems. Why is Latin America lagging behind? This is a good question that deserves closer examination. This article discusses reasons for the chronic problems for the deteriorated conditions facing Latin American universities. It also suggests ways in which Latin American distance universities can contribute to a transformation of the entire university system throughout the region.
\end{abstract}

\section{Introduction}

Latin America is region characterized by enormous potential coupled with serious economic and political problems. In both cases, Latin America's public state-run oncampus and distance universities can and should give decisive answers and guidelines to allow for the sound utilization of Latin America's abundant national resources. Such actions will help advance social development and progress throughout the Latin American region. However, most countries in this region are currently facing exacerbated social realities stemming from socio-economic conditions that have their roots in past shortcomings. During the 1980s and 1990s, many of Latin America's most important public universities were neither upgraded nor modernized. Moreover, their curricula were not modernized and, as a consequence, failed to recognize and address the new and changing socio-economic realities occurring domestically, throughout Latin America, and globally.

How do we resolve these problems? First, Latin America's nation states must fundamentally recognize the central role higher education can play in advancing human and national development. My contention is that current educational and pedagogical processes in both residential and distance universities, many of which have been adopted in other so-called developing countries and regions throughout world, can point Latin America in the right direction - a pathway that will yield effective interrelationships and linkages between knowledge, higher education, and society as a whole. 
When rethinking and restructuring Latin America's university system, higher education policy makers must keep in mind underlying objectives of innovation, quality, equity, and social and cultural pertinence. To achieve these objectives, superficial rhetoric must be permanently cast aside. Doing so, however, arguably represents a serious challenge for many of Latin America's conservative and relatively static institutions. It follows then, that creative tools and processes will be necessary to facilitate a deep and rapid transformation of Latin American's university system. By doing so, Latin America's university system can move forward to generate positive outcomes for Latin American society as a whole. It is within this context that distance and virtual universities can be seen as an alternative to traditional universities, and become drivers of positive social and economic change.

\section{Regional Potentialities and Problems}

From a geographical perspective, Latin America is blessed with an abundance of natural resources. This region of the world is capable of generating tremendous economic wealth and social potential - but this can only happen if these resources are rationally and soundly exploited. Indeed, Latin America's ecology is one of the most diverse on Earth. Here are some statistics to support this assertion:

- Latin America's diverse geography is comprised of humid tropical rain forests, including the Amazonian region, which alone produces approximately 42 percent of the Earth's vegetal biomass and oxygen, life sustaining elements that regenerate our planet's air, soil, water. This statistic can be compared to only 14 percent generated by temperate forests in other continents.

- Three large basins, the Amazon, Orinoco, and Rio de la Plata, comprise one third of the world's total ground water flow.

- Latin America generates 19 percent of the world hydroelectricity, yet only consumes 21 percent of its total hydroelectric generation capacity. In simple terms, there is tremendous potential for redistribution and export of hydroelectric energy to other regions within Latin America.

- Latin America also has three percent of the world's fossil fuel reserves such as the oil and gas reserves found in Venezuela, Mexico, and Ecuador. Exploitation these non-renewable resources are projected to last 50 years or more.

- Latin America has 90 percent (736 million hectares) of arable land under cultivation, representing 12 percent of the Earth's biomass currently under cultivation.

- Latin America is home to 46 percent of all the tropical rain forests in the world, and 23 percent of the Earth's forests.

- Latin America yields 17 percent of the world's cattle production.

From a sociological perspective, Latin America is comprised of countries that share similar cultures and common languages. Sharing the use of Spanish dialects and languages, should allow easy access and economic exchange with other Latin American and Spanish speaking countries around the world. From a cultural, political, and economic point of view, such conditions could result in the creation of powerful economic trading block similar to the European Economic Union. In light of the 
tremendous potential of its natural resources and cultural similarities, Latin America must develop and advance its supportive infrastructures, of which its system of universities is a central building block.

Indeed, those countries and regions that currently hold the balance of power have created social and economic systems premised on "information and knowledge" power structures. In simple terms, technological advances are fundamentally changing the nature of human production, a condition which was outlined by Salvador Arriola (1999), the former permanent Secretary of the Latin American Economic System (SELA) ( http://sela2.sela.org/WM2/WMIO.ASP ): "Previously, economic and social development depended on vast quantities of energy, natural resources, work, and capital. Today, it depends specifically on overall knowledge capacity and the information available.”

In contrast with its inherent potential, the reality is that most Latin American countries are facing serious economic develop problems that require prompt and concerted attention. As Tunnermann (1997) observes:

1. Latin America is home to the world's most unequal wealth distribution ("the most extreme distributive polarization in the world," according to the World Bank). On average, the gap between the richest and poorest populations is 10 to15 times greater than that of industrialized countries, where the ratio is currently six (seven in the Asian countries).

2. Of Latin America's 200 million people, 46 percent live in poverty and 94 million people (22 percent of Latin America's total population) live in abject poverty. The President of the International Development Bank (IDB), Enrique Iglesias, explained, "Throughout history, there is not been a country able to become internationally competitive with 40 percent of its population living in situations of low productivity and poverty."

3. At a rate of 2.3 percent per year, Latin America's population is growing more rapidly than other regions. In 2000, the region's population reached 540 million, 70 percent of which live in urban areas. And of that 70 percent living in urban areas, 30 percent live in large cities with over one million people.

4. Latin America is home to four urban megalopolises: Mexico City, Mexico (population: 26 million); Sao Paolo, Brazil (24 million); Rio de Janeiro, Brazil (13.3 million); and Buenos Aires, Argentina (13.2 million). According to the estimates of the United Nations, 90 percent of Latin America's urban populations currently live in extreme poverty.

5. According to SELA, 60 percent of working age adults are either unemployed or are underemployed, usually in informal sectors of the economy, which historically yield low productivity.

6. According to the figures of the United Nations Conference on Trade and Development (UNCTAD), in 1959 Latin America exported 11 percent of the world total exports. By 1970, this figure was 4.8 percent, and by 1999, only 3.6 percent.

7. Between 1981 and 1992, Latin America suffered an overall trade deficit of about 28 percent. 
Over the past two decades, Latin America's population has become increasingly poor and thus economically marginalized. This can be compared to a small but rich population, whose wealth is tied to the international market economy and who represent a true island of modernity surrounded by a human ocean of poverty.

\section{The Challenges for Latin American Universities}

According to Casas (1997) eight fundamentals must be addressed to overcome the current crisis facing many Latin American countries: 1) adoption of knowledge and information technologies; 2) acknowledgement of the growing importance of globalization and the concomitant process of integration created by globalization; 3) increased social equity in terms of higher education opportunities that will allow regions to become and remain competitive in today's rapidly globalizing economy; 4) universities must adopt new educational technologies and developments; 5) universities must acquire modern technologies and infrastructures necessary to positively influence work and overall productivity throughout Latin America's regions; 6) universities must develop and adopt a new set of pedagogical innovations (e.g., virtual learning); 7) universities must re-train professors, researchers, directors, and administrators to enable them to become more productive and effective; 8) universities must adopt new financing and organizational schemes to support advances in technological and pedagogical innovation. In sum, the growing strategic importance of higher education coupled with the need to reorganize and radically transform Latin America's university system, is essential to help Latin America catch up to other countries around the world. This clearly requires an intensive period of transition to help Latin American countries and their populations at first to survive, then to participate in today's increasingly globalize economy.

In light of the formidable and steadily mounting challenges facing Latin American universities today, one must ask: Under current conditions, can Latin America's universities successfully accomplish the extraordinary task of reform? And if so, can they make the transition quickly enough? To answer this question, I look to a number of research-based studies that reach the disturbing and disheartening conclusion that it is unlikely that change will happen soon enough. In his critical report, "The Latin American University," Atcon (1963) maintained that future development of the region must rely upon a deep reform of its university system. If steps are not undertaken or if they are unsuccessful, the stage will be set for the slow and destructive play Atcon called "social dissolution" to take place. Unfortunately, because of the dominating political ideologies of the 1960s and 1970s, this report's recommendations were largely opposed or ignored. For the next thirty years, several studies defined the problems facing universities and suggested "agendas" for the future reconstruction of Latin America's university systems and institutions. Among the most significant research contributions are: Scherz (1964); Ribeiro (1973); Mayz (1984); Brunner (1985); Albornoz (1993); Garcia (1996); Cresalc/UNESCO (1997); Tunnermann (1998), and Garcia (1997).

A useful way to assess a university's importance in the past, present, and future, is to examine its performance in terms of concepts such as quality, innovation, and pertinence.

1. Latin American universities have proven to be rigid and resistant to change and modernization, conditions that are inimical in today's world, which is faced by deep and accelerated economic and social changes. On the other hand, there has been a dramatic increase of student enrollment in Latin America's education system, but unfortunately, without the corresponding changes in structure, procedures, and resources to support such increase in demand. 
2. The organizational model of many universities in Latin America remains that of the "French, Napoleonic model", with independent professional faculties that do not conform the "collective" concept of a "university." Indeed, there is such a great emphasis in professionalism, current models usually operate in an information silo structure; as a result faculty become intellectually and politically insular, with little possibility of cross fertilization and intellectual transfer. In this context, science and research are not usually considered.

3. "The Chair" is currently the fundamental teaching unit, a position which is often insular, unimpeachable, and usually assigned as some teachers' "rightful property."

4. Learning is mainly based on rote memorization. In many instances, one professor's "notes" often form the only source of information students receive.

5. There remains little interest in developing future academic talent in any integrated or concerted manner.

6. Recruitment and selection of academic personnel are usually made based on political appointment.

7. There is little or no opportunity for poor students to enroll and to complete university degrees.

8. There is an absence of serious policies for research, its integration with teaching, and its direct extension to ameliorate critical social problems.

9. There is an overall absence of modern and functional administrative and managerial systems.

10. In many cases, a university's "pertinence” for its particular social context is irrelevant due to a misconception of its autonomy and the interference of political ideologies.

These and many other important arguments formed the basis for conclusions drawn by the Regional Conference of UNESCO held in Havana in 1997. Citing the urgent need to engage in a deep restructuring of higher education in Latin America, it was determined that such process could be carried out according to some orientating principles as follows:

1. University actions and influence should extend beyond its campus through teaching and research activities. Educational extension should be restructured around national needs and conditions, to help countries to grapple with powerful changes brought about by economic globalization. Networks and strategic alliances must be struck, to help integrate and incorporate complementary talent and programs from other national and international institutions.

2. The topic of Latin American integration must be a main theme for interdisciplinary research. For many universities this will require new areas and forms of research.

3. New universities must be established that allow more flexible academic structures. For instance, they must use the "departmental model" as the basic unit for teaching and research, rather than the traditional and often isolated "chair model” currently in use in most educational institutions. 
4. The new "Informatic-Telematic Paradigm" must be integrated into the structure and operation of all university activities.

5. Universities must operate as integrated communities dedicated to research, and the creation and transmission of knowledge and progress - particularly in science and technology - to a broader class of students. Research and teaching must also be grounded within a context that is relevant to the specific needs of Latin Americans on a regional basis. Universities should no longer be merely seen as "teaching institutions," whose sole goal is conferring professional degrees and certifications, but instead as an active member of the "research community," one which proactively seeks ways and means of addressing Latin America's complex socio-economic problems.

6. Creative forms of learning, aided by new and computer and information technologies, can facilitate the radical changes in educational processes. For instance, "virtual learning" is one such form. There must also be a move towards the "model of lifelong learning," rather than the current model where the concentration of learning takes place at the beginning of one's active life.

7. The framework for training and grooming of future academic talent must be established.

In summary, if Latin America's system of universities continue to hold resolutely to the past, and remain resistant to the evolution, adaptation and the changes necessary for participation in today's increasingly globalized economic landscape, it will be difficult to bring Latin America into a prosperous future that reflects its inherent wealth. To bring about the social and economic conditions for full participation of Latin America in today's global economy, universities must embrace a deep and fundamental change that address all the above.

\section{Insertion of Distance Education in Latin America}

Conditions, resources and requirements of modern industrial and technological societies, demand a profound change to the typical paradigm typical in Latin America's educational and training processes (Garcia Aretio, 1994). Although the transformation of the classical paradigm is applicable to all educational levels, it may be regarded as more critical at the university level. However, some educators who are opposed to such a transformation argue that a simpler solution to the problems facing higher education is for each state or country to supply additional resources to expand and increase the university sector. In my mind, this simplistic view falls short because the problems are much deeper and more complex. A first step toward creation of new paradigm is to find the source of rigidity of traditional education and to find solutions to overcome this rigidity in relation to time and

space. The several elements that define and differentiate current distance and virtual education are shown in Figure 1 (Duart and Sangrá, 2000). 
Figure 1. Educational Coincidence in Space and Time (Duart and Sangra, 2000, p. 29).

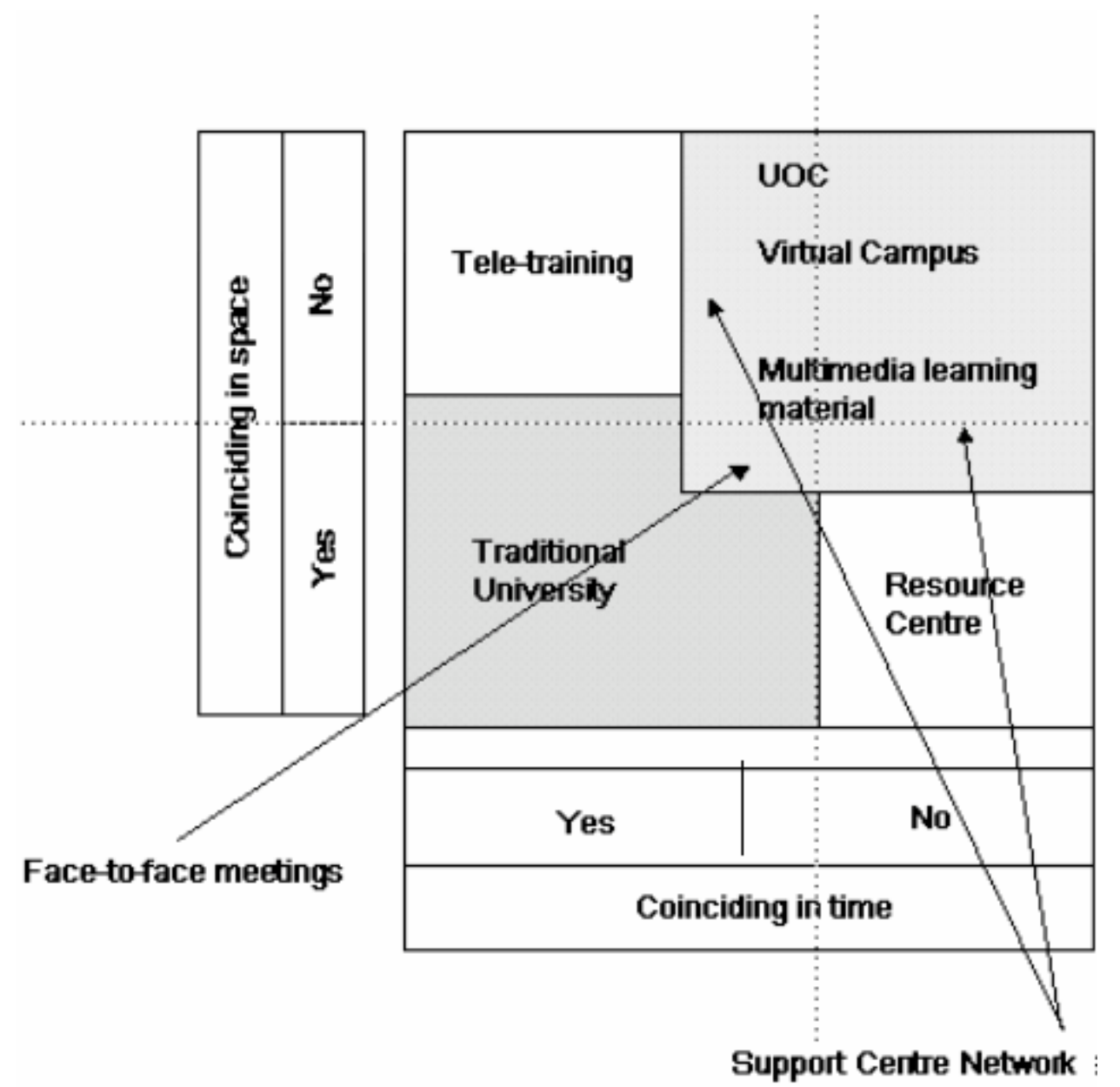

In the search for innovative educational solutions throughout the 1970s, the distance university solution has been progressively building its different structures, procedures, and theoretical frameworks. Although correspondence and radio educational experiences long existed prior to the foundation of the British Open University in 1969, this institution has led to the creation of new distance universities in many countries around the world, including Latin America.

Coupled with the rise of new educational theories and the use of rapidly evolving information and communication technologies, many of Latin America's serious socioeconomic limitations can now be bridged by using open and distance education models. The first two exclusively distance education universities created in Latin America were Costa Rica's Universidad Estatal a Distancia (UNED) and Venezuela's Universidad Nacional Abierta, both established in 1977, and both greatly influenced by the British Open University and Spain's Universidad Nacional Estatal (UNED), which was established in 1972. Prior to this, Mexico had led the way through the development of some important distance learning programs for secondary level education known as "Telesecundaria” in 1971; and at the higher education level, the Autonomous University of Mexico (UNAM) in 1972, both of which were also greatly influenced by the "Open University System,” developed by different professional faculties. In 1996, a private technological institution, Technological Institute for Advanced Studies in Monterrey (ITESM), founded its "Virtual University" based on their experiences, resources, and access to high technology. Their services have now been expanded beyond Mexico to 
other Latin American countries. Following the creation of the universities outlined above, numerous distance education programs have been developed through existing on-campus universities, with heterogeneous characteristics.

\section{Twenty-Five Years of Distance Education in Latin America: A critical view}

During the early years of distance universities and programs, most Latin American politicians and educators viewed the distance education modality as a "remedy" for those who lacked the conditions or economic opportunity to engage in "real" face-to-face studies at a traditional campus-based university. Some felt distance education could reduce costs and provide access to help satisfy increasing demand for higher education throughout Latin American society as a whole. Distance education in this context, however, was usually perceived as a second rate solution to address the training and educational needs of the poorer social classes. Today, these beliefs have changed radically. Distance education is now considered to be the most important educational phenomenon of the 20th and 21st centuries. However, it is also recognized that distance education must be socially relevant and provide the conditions for high quality student achievement. When both conditions of social relevance and high quality student achievement are not duly satisfied, the result is just a massive wave of mediocrity papered with "fake" diplomas - a dangerous condition that holds with it the real potential of hindering positive social progress.

During the initial phase of Latin America's distance universities and programs in the 1970s, the theoretical foundations and purposes were generally well conceived and delineated. However, over time, "content" became the major source of pedagogical concern, unfortunately at the expense of aspects related to distance education design, production, principles, conditions, and evaluation procedures. The net result was a step backwards as the re-establishment of traditional face-to-face courses took preference, albeit with labels borrowed from distance education. This is a clear example of the difficulties inherent during the transition from traditional "present" paradigm, to the new informative-telematic distance learning paradigm.

In some Latin American, cultural traits have become obstacles for experimentation and improvement of distance education. These cultural traits are: a) illusion, b) nominalism, c) postponement, and d) simulation.

a) The distinction between expectations and reality creates an illusion that one is actually being educated.

b) Nominalism assumes that one thing is real only because it has a name. For instance, many programs are labeled "distance education," only because it is considered "fashionable," not because it is actually designed as a distance education course of studies. One such recent instance has been the extended use of the virtual university and virtual learning.

c) Postponement occurs when decisions are slowed down by constant delays.

d) Simulation is the dynamic of concentrating main efforts in one area, giving a misleading appearance of the real thing. 
Planning, research, and evaluation are basic activities required for upholding and preserving the quality and pertinence of any distance university or program. Unfortunately, in the majority of distance Latin American universities, these activities have been neglected mainly because, in practice, they are "teaching universities." Research, on the other hand, requires a team of efficient researchers, something generally difficult to find in a single institution. In fact, if we regard research as the springboard to innovation and construction of solid institutions, this limitation represents one of the most significant obstacles currently facing the advancement of Latin American distance universities.

Many of the problems of Latin American distance universities and programming stem from their incapacity to transform and update their organizational structure, learning processes, recruitment policies, and professional development of their teaching staff. This is a relevant concern, because most are still anchored to the so-called "second generation" of distance education (as defined by Taylor, 1999).

The lack of modern ideas of world globalization and virtualization of universities are still critical issues facing the Latin American context, greatly affecting and undermining the possibilities for substantial change.

At the 2001 meeting of the Ibero-American Association of Distance Higher Education (AIESAD), it was determined that improvement in the quality and advancement of distance education for this region requires correction of such problems as: 1) he lack of norms to regulate proposals, stimulate best practice, and prosecute fraud; 2) tendency to reproduce traditional educational practices in distance education; 3) distrust of some governments regarding their policy on distance education; 4) problems with authors and academics in relation to intellectual property rights; 5) low levels of inter-institutional cooperation; and 6) lack of international agreements that formally recognize programs of learning and govern transfer of academic credits and degrees.

The critical problems requiring answers in Latin American distance universities can be classified as both "general problems" and "specific problems." General Problems comprise tendencies toward improvisation instead of sound planning, development of workable programs without any follow-up, technological / cultural immaturity, resistance to innovation, and political "clientele-ism." Specific Problems comprise high student dropout rates; obsolescence of instructional materials and evaluation methods; low levels of student-to-professor and student-to-student interaction; lack of social pertinence of educational programs; obsolete and inappropriate preparation of professors, researchers, executives, and administrative personnel; dysfunctional organizational structures for distance education unable to meet new academic, social and scientific demands.

\section{Global and Prospective View of Distance Education in Latin America}

Some Latin America countries have distance universities and programs of high quality and concomitant productivity, but they are the exception rather than the rule. However, distance education is still recognized as one of the most important means to generate socio-economic transformation; but to achieve this ideal, present limitations must be overcome and a fundamental restructuring of current organization and procedures needs to be carried out, and without delay. Open and distance learning should not be considered important merely because of the sound of its name or worldwide popularity, but rather because of the quality of its learning, fairness and relevance of its academic 
programming, and its positive effects on other segments of Latin America's educational systems. Moreover, expectations must not be mistaken for reality. The enormous potential of distance education for the Latin America region cannot be achieved overnight. Rather, favorable pre-conditions must be created in order to promote effective learning and knowledge through distance modalities.

Distance education in Latin America, rather than being considered a second rate educational complement for traditional higher education, must be seen as a fundamental engine for restructuring other university systems, especially the public ones. Thus, the entire university sector could foster an effective transformation of their corresponding societies (Casas and Stojanovic, 1999). In this respect, it is important to keep in mind the extraordinary development of computer science and communication technologies that are positively changing the potentialities of Open and Distance Education. Space, time, large scale operation, significant cost reduction, effective support of learning quality - all available through the use of new and emerging information and communication technologies - offer new solutions for advanced planning, production, operation and evaluation techniques. Important changes are being heralded for distance education for Latin America, so long as their systems and institutions have the capacity to implement creative new approaches that recognize and take into consideration their particular worldviews. If the contradiction between diplomas and knowledge is solved in favor of the former, distance education will just be one more "excellent idea," but only for historical record. Here are some ideas are suggested for the restructuring and modernization of Latin American distance education:

- Virtualization, in the form of tapping into the extraordinary educational possibilities offered through the use of new technologies. In this complex process, technologies are used as a means to support the pedagogical principles that underlying effective learning

- Convergence through the use of progressive integration of traditional on-campus and distance universities

- Expansion and consolidation of research at the graduate level as a basic requirement for innovation of distance education modalities that take into consideration the socio-economic condition of the region in which it will be deployed

- Continuous evaluation and accreditation by external boards representing universities, government, and industry at a regional level

- Transformation and consolidation of educational initiatives throughout Latin America. High-caliber inter-institutional and interdisciplinary centers must be created for the training, preparation, and accreditation of academics, directors, and administrative personnel in their use and understanding of distance education modalities

- Establishment of new organizational and functional structures for distance education. Special attention must be given to aspects forming strategic alliances, networks, confederations, etc., and the integration of distance and traditional oncampus universities, public and private, regionally, nationally, and internationally

- Adoption of effective managerial methodologies and procedures - from financial planning to curricula and student evaluation 
As a synthesis of this global and prospective view, one must emphasize that distance universities and programs throughout Latin America have now reached an historical crossroads. To take full advantage of its extraordinary power to generate the fundamental changes required of other educational systems, a prompt and profound restructuring of Latin America's existing distance education system is necessary. If decisive actions continue to be postponed, Latin America's future certainly will be more dismal than it already is.

\section{References}

Albornoz, O. (1993). Education and Society in Latinamerica. Pittsburg PA.University of Pittsburg Press.

Arnove, R. F. (Ed.) (1999). Comparative Education. The Dialectec of the Global and the Local. Oxford: Rowman and Littlefield:

Bates, A. W. (2000). Teaching, Learning, and the Impact of Multimedia Technologies. Boulder CO.: Educause Review. September/October.

Brunner, José Joaquín. (1985). Universidad y Sociedad en América Latina. Un Esquema de Interpretación. Caracas: Cresalc.

Casas Armengol, M., and Stojanovic, L. (1999). Educación a Distancia: Una fuerza decisiva para la reestructuración de la Universidad Latinoamericana. Trabajo presentado a la XIX Conferencia Mundial del ICDE. Vienna.

Casas Armengol, M. (2000a). "Ilusión versus Realidades: Viabilidad de la Universidad Virtual Latinoamericana.” Trabajo presentado a l Conferencia Internacional, Online Educa Madrid 2000: Madrid.

Casas Armengol, Miguel (2000b). Nuevas Fuerzas de Globalización y Virtualización en las Universidades Latinoamericanas. Trabajo presentado en la Conferencia Internacional del Décimo Aniversario del CREAD: Caracas.

Cresalc-Unesco (1997). Hacia una nueva educación superior. Actas dela Conferencia Regional sobre Políticas y Estrategias para la transformación de la Educación Superior en América Latina y el Caribe. Cresalc/ UNESCO: Caracas.

Daniel, J. S. (1996). Universities and Knowledge Media. London: Kogan Page.

Duart, J. M. (2000). Aprender en la Virtualidad. Barcelona: Gedisa.

Garcia Aretio, L. (2001). La Educaciòn a Distancia. De la Teoría a la Práctica. Barcelona: Ariel Educación.

Garcia Guadilla, C. (1996). Conocimiento, Educación Superior y Sociedad en América Latina. Caracas: Cendes-Nueva Sociedad.

Garcia Guadilla, C. (1997). El valor de la pertinencia en las dinámicas de transformación de la educación superior en América Latina. En La educación Superior en el Siglo XXI. Visión de América Latina y el Caribe. Caracas: Cresalc/ UNESCO. 
Armengol - Global and Critical Visions of Distance Universities and Programs in Latin America

Harasim, L. (2000). Redes de Aprendizaje. Barcelona: Gedisa.

Kent, S. R., and Devries, W. (1997). Evaluación y Acreditación de la Educación Superior Latinoamericana: razones, logros, desafíos y propuestas. En La educación superior en el Siglo XXI. Visión de América Latina y el Caribe. Caracas: Cresalc/ UNESCO.

Mayz Vallenilla, E. (1984). El ocaso de las Universidades. Monte Avila ed: Caracas.

McLaren, P. (1999). Critical Education in the Information Age. Oxford: Rowman and Litlefield.

Mason, R. (1998). Globalising Education. Trends and Application. London: Routledge.

Moore, M. G., and Kearsley, G. (1996). Distance Education: A Systems View. Belmont CA.: Wadsworth Publishing Co.

Ribeiro, D. (1973). La universidad nueva. Un proyecto. Buenos Aires: Editorial Ciencia Nueva.

Schank, R. (1997). Virtual Learning. New York: McGraw-Hill.

Sherz Garcia, L. (1964). Una nueva universidad para América Latina. Universidad del Zulia: Maracaibo.

Silvio, J. (2000). La Virtualización de la Universidad. Como podemos transformar la educación superior con la tecnología Caracas: Iesalc/ UNESCO.

Taylor, J. C. (1997). Distance Education: The Fifth Generation. En XIX Conferencia Internacional del ICDE. Vienna, Austria.

Tunnermann Bernheim, C. (1997). La Educación Superior en América Latina y el Caribe, en su contexto económico, político y social. En Hacia una nueva educación superior. Cresalc/ UNESCO: Caracas.

Tunnermann Bernheim, C. (1998). La Educación Superior en el umbral del Siglo XXI. Segunda Edición. Caracas: Cresalc/ UNESCO.

UNESCO/ Cresal (1992). Calidad, Tecnología y Globalización, en la Educación Superior Latinoamericana. Caracas: Cresalc/ UNESCO.

Yarzábal, L. (1999). Consenso para el cambio en la Educación Superior.Ed. Caracas: Iesalc/ UNESCO.
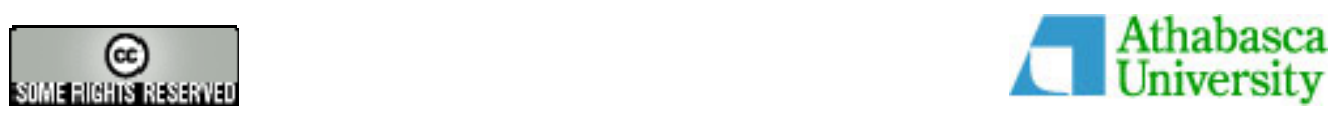